более $30 \%$ опрошенных считают, что разговаривают на нем наиболее свободно. Более 80 \% европейцев считают знание иностранных языков очень полезным, а $67 \%$ опрошенных называют английский одним из двух самых полезных для себя языков, примерно четыре из пяти граждан ЕС считают английский язык одним из самых полезных для будущего своих детей.

Отличается, что высокий уровень владения английским языком демонстрируют молодые люди 15-24 лет; те, которые получил полное дневное образование в возрасте свыше 20 лет; люди, которые живут в больших городах Европейского Союза; те, кто продолжает профессиональное обучение; и люди, которые ежедневно пользуются интернетом. Особую роль в популяризации изучения и использования английского языка на территории Европейского Союза играют школы - более 90 \% учащихся средней школы изучают его именно там. Чуть больше двух третей граждан ЕС изучили иностранный язык именно таким образом.

Опираясь на собранный материал, в исследование демонстрируется, что именно сфера образования играет одну из ведущих ролей в становлении английского как lingua franca современного глобализированного мира в целом и Европейского Союза в частности.

Ключевые слова: английский язык, lingua franca, Европейский Союз, языковая политика, образование, глобализация.

Biskub Iryna, Danylchuk Anna. Education and Globalization: Modern Tendencies in the Study of English in the European Union. The article "Education and Globalization: Modern Tendencies in the Study of English in the European Union" analyzes the statistics collected by the European Commission on the study and use of English in the European Union, its distribution and features of functioning within the EU member states. It is established that the English language plays a particularly important role in the professional, educational and scientific environment, as well as in the field of international cooperation and Internet communication.

The influence of the educational sphere of the European Union on the formation and support of English as a lingua franca within the EU has been traced (even after Brexit). English is traditionally one of the five most common foreign languages spoken by the EU citizens, and although the European Union implements the policy of multilingualism at the institutional level, most citizens prefer to learn English as their first (main) foreign language. In 19 of the 25 Member States where English is not the official or state language, it remains the most widely spoken foreign language, and more than 30 percent of respondents believe that they speak it most fluently. More than 80 percent of Europeans find foreign language skills very useful, 67 percent say English is one of the two most useful languages, and about four in five EU citizens consider English to be one of the most useful languages for their children's future.

The article shows that the highest level of English skills is demonstrated by young people aged 15 to 24 ; those who received a full-time education over the age of 20; people living in major cities of the European Union; those who continue their professional training; and people who use the Internet daily. Schools play a special role in promoting the study and use of English in the European Union - more than 90 percent of high school students study it there. Just over two thirds of EU citizens have learned a foreign language this way. Based on the collected material, the study demonstrates that the field of education plays a leading role in the formation of English as the lingua franca of the modern globalized world in general, and the European Union in particular.

Key words: English language, lingua franca, European Union, language policy, education, globalization.

DOI: https://doi.org/10.32782/2410-0927-2020-13-4

УДК 811.111’271:305:324

Ірина Біскуб, Анна Данильчук

\title{
ФІЛОСОФІЯ ТА ПОЛІТИКА В КРИТИЧНОМУ АНАЛІЗІ ДИСКУРСУ НОБЕЛІВСЬКОЇ ЛЕКЦЇ̈ БЕРТРАНА РАССЕЛЛА
}

У статті наведено критичний аналіз дискурсу Нобелівської промови провідного британського філософа, логіка, письменника, політичного діяча, лауреата Нобелівської премії з літератури 1950 р. Бертрана Расселла. Запропонований критичний аналіз дискурсу виконано із застосуванням нового міждисциплінарного методу, що передбачає виявлення ідеологічного забарвлення дискурсивного фрагмента, залучення ретроспективного огляду системи людських цінностей пост воєнного світу середини ХХ ст. Установлено, що основною комунікативною стратегією дискурсу Б. Расселла є стратегія раціоналізму, завдяки якій він реалізовує власний матеріалістичний світогляд, поєднуючи авторську риторику з логічними аргументами. Доведено, що задля активізації мисленнєвої діяльності слухачів і дотримання стратегії аргументації лектор задіює авторську епізодну автобіографічну та семантичну соціокультурну пам'ять. Запропонований аналіз уможливив виявлення 16 семантичних макропропозицій, що окреслюють головні теми промови. Ідентифіковано ключові поняттями зазначеної промови, до яких належать desire, power та excitement, котрі формують концептуальне ядро лекції. На другому етапі критичного аналізу дискурсу виявлені локальні дискурсивні зміни в лексичній семантиці понять desire, power та excitement, що порівнюються зі словниковими дефініціями. Кількісний аналіз продемонстрував, що найчастотнішим

(С Біскуб I., Данильчук А., 2020 
словосполученням промови $є$ love of power, ужитий автором у тексті 16 разів. Зафіксовані невідповідності в значенні понять засвідчують надмірну ідеалізацію їхніх концептуальних значень, яку автор викриває в контексті своєї промови, надаючи їм нових референтних смислів. Установлено, що базовими ідеологіями Бертрана Расселла в його промові були ідеологія матеріалістичного раціоналізму, демократії та пацифізму. Проведений аналіз дав змогу виявити глибинні концептуальні метафори, які сформувались унаслідок концептуального блендингу. Застосування цих метафор дало змогу прямо вказати на глибинні недоліки й приховані низькі бажання людської спільноти, уникаючи засуджень та персональних звинувачень.

Ключові слова: критичний аналіз дискурсу, семантичні макропропозиції, локальні значення, ідеологія, комунікативна стратегія.

Вступ. Досвід останніх десятиліть розвитку науки засвідчує неабиякий прогрес у галузі прикладних досліджень, що супроводжується появою нових міждисциплінарних напрямів. Проте, треба зазначити, що фундаментальні дослідження також піддаються впливу міждисициплінарності [6]. Це неабияк підвищує зацікавлення представників різних галузей науки питаннями створення ефективних моделей комунікації, здійснення вербального та невербального впливу на реципієнтів, оптимізації використання мови в конкретних комунікативних контекстах [4].

Сучасна дискурсологія як один із найперспективніших напрямів лінгвістики має чіткий прикладний і міждисциплінарний вектори [1]. У світлі інтегративних процесів, характерних для антропоцентричної наукової парадигми, важливі дослідження суспільно-соціальних та філософських аспектів вербальної комунікації [6]. Актуальність запропонованої роботи зумовлена зростанням ролі міждисциплінарних студій і відсутністю верифікованих методів лінгвістичних досліджень, які б давали змогу застосувати міждисциплнарні методики до вивчення мовного матеріалу.

Філософська проблематика завдяки глобальному поширенню синергетики та синергетичних методів дослідження перебуває в постійному фокусі уваги не лише лінгвістів, а й політологів, соціологів, генетиків та нейрофізіологів. Сучасний етап розвитку науки вже називають активним поверненням до раціоналізму [4]. Ідеться про формування так званого «раціонального дискурсу»: “In rational discourse one strives to arrive at justified true belief" [4, с. 4].

Методи та методики дослідження. Зауважимо, що в центрі будь-якої наукової діяльності постає раціональна діяльність. Науковий раціоналізм проявляється через логічний формалізм, сукупність чітких наукових методів, евристик, імовірнісну статистику, теорію прийняття рішень. Усі зазначені прояви в науці мають ознаки нормативності, тобто цілковитого дотримання визначних правил за будь-яких обставин.

Сучасна когнітивна лінгвістика частково перебуває на роздоріжжі, оскільки концепт як основна одиниця дослідження визначається як ментальна репрезентація дійсності, одиниця мислення, що позбавляе концептологічні студії можливості верифікувати результати за допомогою єдиної універсальної методології. Одне 3 останніх визначень концепту в українському мовознавстві знаходимо в С. І. Потапенка: «Концепт - це лінгвокогнітивний конструкт, тобто ідеальний об'єкт, що відтворений у свідомості дослідника, моделює мовленнєву та мисленнєву діяльність людини спираючись на дані лінгвістики, когнітивних наук та культурології» [5, с. 245]. Це релевантне визначення, вочевидь, підкреслює всю суб'єктивність епістеміологічних знань сучасної когнітивної лінгвістики.

Тому, на нашу думку, сучасна дискурсологія не настільки активно апелює до концептуального аналізу, надаючи перевагу психолінгвістичним методикам, які мають більш емпіричний характер, як-от: робота пам'яті, виокремлення семантичних макропропозицій, дотримання когезії й когерентності, вивчення сугестивного впливу та дослідження ідеологій [3].

Попри наявний прогрес у дискурсивних студіях і появу нового найбільш прикладного методу - методу критичного аналізу дискурсу [2], усе ще невизначеним залишається питання щодо того, які саме ментальні конструкти (концепти) задіяні в обчисленнях, котрі постійно виконує мозок людини. Іншими словами, як категорії диференціальні ознаки й зв'язки кодуються мозком людини для подальшого трансформування в поведінку, досвід та інтелект людини [1]. У цьому контексті категорія раціональності залишається частково поза увагою дослідників, оскільки вся когнітивна й інтелектуальна діяльність людини визнається раціональною. 
Результати та дискусії. У цій статті пропонуємо залучити категорію раціональності до критичного аналізу дискурсу однієї з найвизначніших Нобелівських промов - промови лауреата Нобелівської премії з літератури 1950 р. Бертрана Расселла. Б. Расселл - британський філософ, логік, письменник [8]. Попри неоціненний внесок у розвиток аналітичної філософії XX ст., який порівнюють із впливом Арістотеля, Б. Расселл отримав відзнаку саме з літератури, оскільки його унікальна здатність генерувати глибокі за змістом та унікальні й довершені за формою тексти дає підстави вважати його майстром слова [8]. Вочевидь, сама подія - інавгураційна промова під час вручення Нобелівської премії - підсилила його талант красномовства. Тому текст лекції “What Desires Are Politically Important?”, безпереречно, вартий уваги дослідників [7].

Застосовуючи класичну методику критичного аналізу дискурсу, запропоновану Т. ван Дайком [3], на першому етапі ми виокремили 16 семантичних макропропозицій (SM), які формують словесний дизайн промови [7]:

SM1. Introduction: an account of psychology in politics and political theory.

SM 2. All human activity is prompted by desire.

SM 3. The primary group of politically important desires includes the necessities of life: food and shelter and clothing.

SM 4. Acquisitiveness - the wish to possess as much as possible of goods.

SM 5. Vanity (the «Look at me» desire) is one of the most fundamental desires of the human heart.

SM 6. The causal efficacy of love of power is by far the strongest motive in the lives of important men.

SM 7. Love of excitement which makes the populace applaud when war breaks out.

SM 8. An innocent outlet for the unused physical energy produces love of excitement.

SM 9. Civilized life has grown altogether too tame, and it must provide harmless outlets for the impulses which our remote ancestors satisfied in hunting.

SM 10. It is normal to hate what we fear, and it happens frequently, though not always, that we fear what we hate.

SM 11. Two ways of coping with fear: one is to diminish the external danger, and the other is to cultivate Stoic endurance.

SM 12. Ideologies are one of the methods by which herds are created, and the psychology is much the same however the herd may have been generated.

SM 13. Sympathy has produced the many humanitarian advances of the last hundred years.

SM 14. Politics is concerned with herds rather than with individuals.

SM 15. If men were actuated by self-interest, which they are not - except in the case of a few saints - the whole human race would cooperate.

SM 16. The main thing needed to make the world happy is intelligence.

Наведений вище перелік макропропозицій засвідчує надзвичайно широкий як для Нобелівської промови спектр тем, що їх торкнувся Б. Расселл. Водночас за більше ретельного вивчення всі вони виявляються майстерно підпорядкованими загальній глобальній темі - впливу психології людини на політику. Проведемо критичний аналіз цього унікального й історично вагомого дискурсивного фрагмента.

Зауважимо, що для Расселла-науковця та Расселла-мовця домінуючою комунікативною й когнітивною стратегією є раціоналізм. Уся промова пронизана логічними та раціоналістичними аргументами, кожен із яких грунтується на попередніх, супроводжується авторськими прикладами й афоризмами. Усі 16 макропропозицій можна вважати афористичними за змістом і за формою.

Однією 3 тактик стратегії раціоналізму є тактика екземпліфікації, коли мовець наводить когерентні приклади, активуючи різні типи пам'яті. Т ван Дайк розмежовує епізодну та семантичну пам'ять [3, с. 64]. Епізодну пам'ять він також називає особистою, або автобіографічною, пам'яттю. Вона включає зафіксований і структурований авторський досвід мовця, яким він готовий поділитися під час дискурсивної комунікації. Епізодна пам'ять може бути короткотривалою та довготривалою. Семантична пам'ять за своєю природою належить до соціокультурних категорій, вона властива більшості (якщо не всім) членам мовної спільноти, містить історичні, соціальні, культурні, релігійні та наукові знання й дає змогу апелювати до спільних понятійних категорій та концептів під час 
комунікації [3, с. 65]. Семантична соціокультурна пам'ять належить до довготривалої та постійно розширюється впродовж життя людини.

Бертран Расселл у своїй промові вміло застосовує обидва типи пам'яті. Говорячи про жагу до збагачення - acquisitiveness - й визначаючи іiі місце серед усіх людських бажань, третій Граф Расселл видає елемент власної автобіографічної пам'яті та згадує приклад із дитинства про непереборне прагнення естонських дівчат, котрі пережили голод, постійно красти й накопичувати їжу. Далі він поєднує його зі знаннями, видобутими зі спільної соціокультурної пам'яті людства - досвід багатія Рокфеллера та арабських бедуїнів із накопичення й переховування багатства:

"I once befriended two little girls from Estonia, who had narrowly escaped death from starvation in a famine. They lived in my family, and of course had plenty to eat. But they spent all their leisure visiting neighbouring farms and stealing potatoes, which they hoarded. Rockefeller, who in his infancy had experienced great poverty, spent his adult life in a similar manner. Similarly the Arab chieftains on their silken Byzantine divans could not forget the desert, and hoarded riches far beyond any possible physical need" [7].

Таким способом мовець ідентифікує себе з рештою людей, які мають спільні цінності й спільний досвід їх застосування для вирішення життєвих ситуацій.

Другий етап критичного аналізу дискурсу - аналіз локальних значень, що їх набувають слова в дискурсі. Розглянемо деякі цікаві приклади семантичних девіацій під впливом дискурсивного контексту. Для виявлення відтінків дискурсивних значень ми порівняли словникові дефініції ключових слів desire, power та excitement із їхніми дискурсивними смислами. Результати порівняння наведено в табл. 1.

Таблиия 1

Порівняльний аналіз словникових та локальних дискурсивних значень

\begin{tabular}{|c|c|c|c|}
\hline Лексема & $\begin{array}{c}\text { Словникове значення } \\
\text { (Merriam-Webster Dictionary online) }\end{array}$ & \begin{tabular}{|c|} 
Локальне \\
дискурсивне \\
значення
\end{tabular} & Приклад [7] \\
\hline 1 & 2 & 3 & 4 \\
\hline Desire & $\begin{array}{l}\text { : conscious impulse } \\
\text { (see IMPULSE_ENTRY 1 SENSE 1) toward } \\
\text { something that promises enjoyment or } \\
\text { satisfaction in its attainmentridding oneself of } \\
\text { all desireshow humans process desire } \\
\text { 2a: LONGING, CRAVINGteenagers' desire } \\
\text { for independence... the inexpensive } \\
\text { homebuilt craft that satisfy many } \\
\text { people's desire to fly_ James Fallows } \\
\text { b: sexual urge or appetite } \\
\text { 3: something longed or hoped } \\
\text { for: something desiredYou are my } \\
\text { heart's desire. } \\
\text { 4: a usually formal request or petition for } \\
\text { some actionat the desire of one fifth of those } \\
\text { present. }\end{array}$ & $\begin{array}{l}\text { A driving } \\
\text { force for } \\
\text { human } \\
\text { activity/. }\end{array}$ & $\begin{array}{l}\text { All human activity is } \\
\text { prompted by desire. } \\
\text { Man differs from other } \\
\text { animals in one very } \\
\text { important respect, and that is } \\
\text { that he has some desires } \\
\text { which are, so to speak, } \\
\text { infinite, which can never be } \\
\text { fully gratified, and which } \\
\text { would keep him restless even } \\
\text { in Paradise. }\end{array}$ \\
\hline Power & $\begin{array}{l}\text { 1a(1): ability to act or produce an effect } \\
\text { (2): ability to get extra-base hits } \\
\text { (3): capacity for being acted upon or } \\
\text { undergoing an effect } \\
\text { b: legal or official authority, capacity, or } \\
\text { right } \\
\text { 2a: possession of control, authority, or } \\
\text { influence over others }\end{array}$ & $\begin{array}{l}\text { 1. Power is } \\
\text { desire; } \\
\text { 2. the way to } \\
\text { tyranny. }\end{array}$ & $\begin{array}{l}\text { 1. Power, like vanity, is } \\
\text { insatiable. Nothing short of } \\
\text { omnipotence could satisfy it } \\
\text { completely. } \\
\text { 2. In any autocratic regime, } \\
\text { the holders of power become } \\
\text { increasingly tyrannical with } \\
\text { experience of the delights }\end{array}$ \\
\hline
\end{tabular}




\begin{tabular}{|c|c|c|c|}
\hline & $\begin{array}{l}\text { b: one having such powerspecifically: a } \\
\text { sovereign state } \\
\text { c: a controlling } \\
\text { group : ESTABLISHMENT —often used in } \\
\text { the phrase the powers that be } \\
\text { d } \text { archaic: a force of armed men } \\
\text { echiefly dialectal : a large number or } \\
\text { quantity } \\
\text { 3a: physical might } \\
\text { b: mental or moral efficacy } \\
\text { c: political control or influence }\end{array}$ & $\begin{array}{l}3 . \quad \text { an } \\
\text { instrument of } \\
\text { pain }\end{array}$ & $\begin{array}{l}\text { that power can afford. } \\
\text { 3. Since power over human } \\
\text { beings is shown in making } \\
\text { them do what they would } \\
\text { rather not do, the man who is } \\
\text { actuated by love of power is } \\
\text { more apt to inflict pain than } \\
\text { to permit pleasure. }\end{array}$ \\
\hline Excitement & $\begin{array}{l}\text { 1: something that excites or rouses } \\
\text { 2: the action of exciting : the state of } \\
\text { being excited }\end{array}$ & $\begin{array}{l}\text { A form of } \\
\text { destruction }\end{array}$ & $\begin{array}{l}\text { What is serious about } \\
\text { excitement is that so many of } \\
\text { its forms are destructive. It is } \\
\text { destructive in those who } \\
\text { cannot resist excess in alcohol } \\
\text { or gambling. It is destructive } \\
\text { when it takes the form of mob } \\
\text { violence. And above all it is } \\
\text { destructive when it leads to } \\
\text { war. It is so deep a need that it } \\
\text { will find harmful outlets of this } \\
\text { kind unless innocent outlets } \\
\text { are at hand. }\end{array}$ \\
\hline
\end{tabular}

Як засвідчує аналіз виявлених дискурсивних локальних значень, ключові слова desire, power та excitement у дискурсі Нобелівської промови Б. Расселла отримали низку нових відтінків, які, передусім, характеризують ідеологічне наповнення самого мовця. Бертран Расселл - відомий усьому світу матеріаліст, автор теорії нейтрального монізму, атеїст [8]. У своїх працях він поєднав емпіричний рівень опрацювання фактів із раціоналістичною логікою суджень, завдяки чому раціоналізм надійно закріпився у матеріалістичній філософії XX ст. Саме тому у своїй лекції вчений визначає людські бажання (desires) як рушійну силу людської діяльності, відходячи від суто психологічного тлумачення цього поняття й надаючи йому цілком раціонального змісту. Отже, однією з ідеологій, як пропагує Б. Расселл у своїй промові, є ідеологія раціоналізму.

Наступна ідеологія, котра простежується в промові Б. Расселла - раціоналістична демократія. Попри високе аристократичне походження та консервативне виховання, Нобелівський лауреат Бертран Расселл усе життя виступав за дотримання принципів демократії, рівності, свободи слова й думки. У багатьох працях він торкався розуміння поняття «влада» ("power"). У дискурсі Нобелівської лекції Бертран Расселл неодноразово використовує словосполучення "love of power"

- Much that passes as idealism is disguised hatred or disguised love of power.

- Love of power is closely akin to vanity, but it is not by any means the same thing.

- And as it is especially the vice of energetic men, the causal efficacy of love of power is out of all proportion to its frequency. It is, indeed, by far the strongest motive in the lives of important men.

- Love of power is greatly increased by the experience of power, and this applies to petty power as well as to that of potentates.

- The man who is actuated by love of power is more apt to inflict pain than to permit pleasure.

- In politics, also, a reformer may have just as strong a love of power as a despot [7].

У своїй промові Б. Расселл уживає словосполучення love of power_16 разів, що свідчить про неабияку зацікавленність самого автора цим феноменом. Із властивим йому раціоналізмом, об'єктивністю й подекуди суцільною відсутністю сентиментів великий оратор розкриває всі потаємні сторони однієї з найсильніших пристрастей людини - любові до влади. Це таємне 
бажання подається автором і як певний ідеалістичний світогляд, інколи дуже наближений до марнославства. Усі видатні люди в глибині володіють цією властивістю. Любов до влади збільшується з ііі відчуттям, тобто після власного втілення в життя. Людина, наділена любов'ю до влади, більше схильна чинити зло, аніж добро. У політиці любов до влади має однакову силу як для реформаторів, так i для деспотів. Такі думки наповнюють Нобелівську промову Б. Расселла гострою, проте реалістичною критикою темних сторін людської натури, про які не прийнято говорити вголос. А вчений ставить це в центр своєї унікальної публічної лекції.

Наприкінці проаналізуємо декілька непересічних концептуальних метафор, які $є$ настільки оригінальними за своєю суттю, що й досі залишають незабутній ефект у свідомості кожного, хто занурюється в дискурс Нобелівської лекції Б. Расселла. Зауважимо, що цей текст написаний автором саме для публічного виголошення, тому правильному підбору метафоричних образів автор приділив багато уваги.

Расселл відверто говорить про хворобливу пристрасть людей до вбивств, ведення війни. Він сприймає їх як психологічні девіації, які можна приборкати цивілізованим способом. Мало хто в середині XX ст. відважувався говорити про це вголос. Проте Б. Расселл застосовує блискучу концептуальну метфору TO LIVE IS TO RELEASE ENERGY, усередині якої простежуємо метафоричний блендинг: to live is to kill, to kill is to release energy:

In Australia, where people are few and rabbits are many, I watched a whole populace satisfying the primitive impulse in the primitive manner by the skillful slaughter of many thousands of rabbits. But in London or New York some other means must be found to gratify primitive impulse. I think every big town should contain artificial waterfalls that people could descend in very fragile canoes, and they should contain bathing pools full of mechanical sharks. Any person found advocating a preventive war should be condemned to two hours a day with these ingenious monsters [7].

Автор метафорично називає вбивство примітивним імпульсом - satisfying the primitive impulse. Принагідно зауважимо, що Б. Рассел не вдається до моралізації та критики вбивств, пропонуючи альтернативний спосіб задоволення цієї низької потреби в людей, котрі проживають у цивілізованому світі. Створення в містах штучних водоспадів, 3 яких людині потрібно буде спуститись у невеличкому каное, проминувши також басейни 3 механічними акулами - ось як геніальний Бертран Расселл пропонує розв'язати проблему нав'язливого бажання деяких політиків почати війну. Перш ніж, як приймати доленосні рішення, політикам треба пройти крізь важкі фізичні випробовування, витратити багато фізичної енергії, відчути небезпеку й реальну загрозу власному життю - i лише після цього втягувати у війну інших людей. На думку Б. Расселла, кількість війн, розпочатих політиками після таких випробувань, буде мінімальною.

Зважаючи на це, можемо зробити висновок, що основна ідеологія Бертрана Расселла як особистості - це раціональний пацифізм. Автор недвозначно натякає:

I have never heard of a war that proceeded from dance halls [7].

Висновки. Отже, на підставі наведеного критичного аналізу дискурсу Нобелівської лекції Бертрана Расселла вважаємо, що розглянутий дискурсивний зразок $є$ прикладом філософсько-політичної промови, яка репрезентує ідеологічний підсумок розвитку людської цивілізації після Другої світової війни. Із позицій стратегії раціоналізму автор інвентаризує систему цінностей, викриває темні риси людської природи, апелює до здорового глузду. Виявлені локальні дискурсивні зміни в лексичній семантиці таких ключових понять, як desire, power та excitement засвідчують надмірну ідеалізацію їхніх концептуальних значень, котру Б. Рассел викриває в контексті своєї промови, надаючи їм нових референтних смислів. Нобелівська лекція була, безумовно, політичною промовою, тому автор уміло екстраполював на аудиторію три свої ключові ідеології - раціоналізму, демократії та пацифізму. Уважаємо, що ця беспрецедентна промова не втратила актуальності й у наш час і заслуговує на подальшу увагу філософів, політиків та лінгвістів.

\section{References}

1. Biskub, Iryna. 2017. "Cognitive, Social and Communicative Levels of Discourse Analysis: The Case of Critical Discourse Study". Language Culture Politics. International Journal 1: 21-37.

2. Dijk, Teun. A van. 2008. Discourse and Context. A sociocognitive approach. Cambridge: Cambridge University Press. 
3. Dijk, Teun. A van. 2002. Critical Discourse Studies: A Sociocognitive Approach. Wodak, R. and Meyer, M. (eds) (2002) Methods of Critical Discourse Analysis. London; Sage, 62-86.

4. Jackendoff, Ray. 1995. Languages of the Mind. Essays on Mental Representations. Cambridge; Massachussetts; London: The MIT Press.

5. Potapenko, S. 2018. Linguistic conceptology: What Is Next? Doctrina Multiplex, Veritas Una. Kyiv: Borys Grinchenko University of Kyiv, 242-259.

6. Prykhodko, Anna. 2018. Interdisciplinary Character of the Evaluation Category. Doctrina Multiplex, Veritas Una. Kyiv: Borys Grinchenko University of Kyiv, 260-272.

7. Russell, Bertrand. 1950. Nobel Lecture. What Desires Are Politically Important? URL: https://www.nobelprize.org/prizes/literature/1950/russell/lecture/

8. Russell, Bertrand. 1950. Biographical. URL: https://www.nobelprize.org/prizes/literature/1950/ russell/biographical/

Бискуб Ирина, Данильчук Анна. Философия и политика в критическом анализе дискурса Нобелевской лекции Бертрана Расселла. В статье приводится критический анализ дискурса Нобелевской речи ведущего британского философа, логика, писателя, политического деятеля, лауреата Нобелевской премии по литературе 1950 г. Бертрана Расселла. Предложенный критический анализ дискурса проводился с использованием нового междисциплинарного метода, предусматривающего выявление идеологической тональности дискурсивного фрагмента, употребление ретроспективного анализа системы общечеловеческих ценностей пост военного мира середины XX в. Отмечается, что основной коммуникативной стратегией дискурса Б. Расселла является стратегия рационализма, благодаря которой, он реализует свое собственное материалистическое мировоззрение, объединяя авторскую риторику с логическими аргументами. Доказывается, что с целью активизации мыслительной деятельности слушателей, лектор задействует авторскую эпизодную автобиографическую, а также семантическую социокультурную память. В предлагаемом анализе выделяется 16 семантических макропропозиций, указывающих на главные темы речи. Идентифицируются ключевые понятия проанализированной речи, к которым относятся desire, power и excitement, формирующие концептуальное ядро лекции. На втором этапе критического анализа дискурса определятся локальные дискурсивные изменения в лексической семантике понятий desire, power и excitement, которые приводятся в сравнении со словарными определениями. Количественный анализ показал, что наиболее частотным словосочетанием речи является love of power, употребленное автором в тексте 16 раз. Зафиксированые несоответствия в значении понятий свидетельствуют о чрезмерной идеализации их концептуальных значений, которую ученый задействовал в контексте своей речи, предоставляя им новые референтные смыслы. Устанавливается, что базовыми идеологиями Бертрана Расселла в его речи являются идеология материалистического рационализма, демократии и пацифизма. Проведенный анализ помог выявить глубинные концептуальные метафоры, которые сформировались в результате концептуального блендинга. Применение этих метафор позволило Б. Расселу прямо указать на глубинные недостатки и скрытые низкие желания человеческого сообщества, избегая осуждения и персональных обвинений.

Ключевые слова: критический анализ дискурса, семантические макропропозиции, локальные значения, идеология, коммуникативная стратегия.

Biskub Iryna, Danylchuk Anna. Philosophy and Politics in Critical Discourse Analysis of Bertrand Russell's Nobel Lecture. The article presents a critical discourse analysis of the Nobel lecture of the leading British philosopher, logician, writer, politician, 1950 Nobel Prize winner in literature Bertrand Russell. The proposed critical analysis of B. Russell's discourse was performed using a new interdisciplinary method, which involves identifying the ideological coloring of the discourse fragment, involving a retrospective review of the human values of the mid-twentieth century's post-war world. The main identified communicative strategy of B. Russell's discourse is the strategy of rationalism, with the help of which he shares his own materialist worldview, combining the author's rhetoric with bare logical arguments. It has been noted that in order to activate the mental activity of the listeners and adhere to the strategy of argumentation, the lecturer appeals to his own episodic autobiographical memory and common semantic socio-cultural memory. The proposed analysis made it possible to extraxt 16 semantic macropropositions underlying the main topics of the speech. The key concepts of the analyzed lecture are identified, which include desire, power and excitement, predefining the conceptual core of the lecture. The second stage of critical discourse analysis reveals local discursive changes in the lexical semantics of the above mentioned concepts of desire, power and excitement. The shifts in meaning are given in comparison with dictionary definitions. Quantitative analysis showed that the most frequently used collocation of the Nobel lecture is love of power, used by the author 16 times in the text. The indicated shifts in the meaning of the concepts point out the excessive idealization of their generalized meanings, exposed by the author in the context of his speech, assigning them with new referencial meanings. The suggested critical discourse analysis has demonstrated that the basic Bertrand Russell's ideologies activated in his speech were the ideology of materialist rationalism, democracy and pacifism. The analysis made it possible to identify specific author's conceptual metaphors emerging as a result of conceptual blending. The application of these metaphors allowed the author to directly point out the deep flaws and hidden low desires of the humanity, avoiding condemnations and personal accusations.

Keywords: critical discourse analysis, semantic macropropositions, local meanings, ideology, communicative strategy. 